\title{
Is a New Asian Monetary Fund Emerging?
}

https://doi.org/10.21272/sec.5(4).35-45.2021.

Dr. Debesh Bhowmik, ORCID ID: https://orcid.org/0000-0002-0293-1066

Ex-Principal and Honorary Research Professor, Lincoln University College, Malaysia

\begin{abstract}
The plan initiated by Japan for forming an Asian Monetary Fund in a mode of ASEAN +3 countries after Asian financial crisis in 1997 was not realised due to opposition from USA, IMF and China and the plan was revamped through CMI multilateral currency swap and pacific nation's joining with US Dollar hegemony but at present it is confronting Chinese supremacy over the region. Thus, in this paper the author thought of forming a new Asian bloc consisting of SAARC, ASEAN, GCC, China, Japan and Korea for which a new framework of Asian Monetary Fund can be set up with a view to not only supplying additional liquidity in crisis period as well as for developmental finance but also can function for issuing a common currency of the new Asian bloc that is a currency basket which will be formed by currencies of China, Japan and Korea and the currencies of blocs viz SAARC, ASEAN and GCC where unit of account of currency will be measured by gold or silver and the exchange of currency unit of Asia is primarily fixed with Chinese Yuan. The exchange rates of all currencies in the basket will be calculated daily through floating exchange rate mechanism in Asian bloc and common currency will also be floated in SDR basket if CUA is included in SDR basket. The exchange rates will be maintained by Asian Monetary Fund through target zone of $\pm 2.5 \%$ fluctuation. The plan also requires monetary and trade integration as well as political integration with the implementation of Asian stock exchange institute, Asian Parliament, Asian Security council, Asian Central Bank and Asian Clearing Union respectively. The common barriers like Sino-Japan rivalry, US dollar hegemony, non-cooperation from IMF, premature OCA criteria and low capital market internationalisation may delay the process of Asian Economic Integration towards formation of a new Asian Monetary Fund.
\end{abstract}

Keywords: Asian Monetary Fund, Chiang Mai Initiative, ASEAN+3, monetary integration, capital market integration, common currency, SAARC, GCC.

JEL Classification: C20, C58, E44, E52, F02, F15, F30, F33, F40, F45, F53, F55, F65, G10, G20.

Cite as: Debesh Bhowmik (2021). Is a New Asian Monetary Fund Emerging? SocioEconomic Challenges, 5(4), 35-45. https://doi.org/10.21272/sec.5(4).35-45.2021.

Received: 18.10.2021 Accepted: 29.11.2021 Published: 30.12 .2021

Copyright: (C) 2021 by the author. Licensee Sumy State University, Ukraine. This article is an open access article distributed under the terms and conditions of the Creative Commons Attribution (CC BY) license (https://creativecommons.org/licenses/by/4.0/).

\section{Introduction}

Haruhiko Kuroda, the Director of the International Bureau of Ministry of Finance had developed the idea of Asian Monetary Fund and Sakakibara and Kuroda gave leadership support to promote AMF so that the financial authorities of Japan proposed the creation of an Asian Monetary Fund during the G7 meeting in Hongkong in September 20-25,1997 just after the Asian financial crisis. USA, US treasury secretary, IMF had strongly opposed this proposal. China was silent on this issue. Later, ASEAN and Korea have supported that idea. Japan felt that IMF is not sufficient to supply liquidity in Asia during crisis period when AMF may be independent authority to solve the problem easily without intervention of IMF. In case of ASEAN+3, Japan clearly showed its view that it can not be substitute of IMF but Asia needs a regional independent monetary institute that can 
solve Asia's liquidity crisis for Asian development process without fearing structural adjustment and conditionality.

Later, on the question of leadership issue, the extended ASEAN+3 with Asia -Pacific regions and USA the discussion behind formation of AMF was carried through by admitting USA's leadership and IMF's intervention and opposing China's leading role in trade, politics and finance. Now, the original idea of building AMF has transformed into international problems of relationship in economic dominance. A few theoreticians called it a development model of Asian capitalism vs Anglo-American capitalism. Narine (2003) said that the AMF should replace the IMF in Asia. It should promote and defend a model of "Asian developmental capitalism" that is more appropriate for Asia than the Anglo-American model promoted by the IMF. Towards the road of successful CMI process, Asami (2001) argued that both IMF and EU gave green signal to bilateral and multilateral currency swap in Chiang Mai Initiative and have no opposition to continue to develop ASEAN +3 economic and monetary integration and agreed the process of common currency for ASEAN and SAARC. Therefore, all these steps claim for establishing a separate institution for Asia like Asian Monetary Fund for solving liquidity problem and currency management. Yet, during last 12 years, a little development had occurred towards AMF in the negative attitudes. Thus, Lee (2010) had clear idea about the failure proposal of building Asian Monetary Fund by Japan who had given priority of all agreements of ASEAN+3 process of monetary integration which had an extension of CMI. Since USA had no interest in ASEAN+3 as of out of partner and had given veto to set up AMF and Japan had been continuously confronting challenges from China's domination in Asia during many centuries then Asian monetary sovereignty might also unfulfilled. In addition to that Rahman (2016) explored that the agreement of CMI granted the common history in the emergence of the region where the ineffectiveness of APEC and ASEAN is granted and all members of CMI stated that the IMF and USA have initially misinterpreted the regional monetary and exchange cooperation problems.

In this paper the author felt that ASEAN+3 are not the all countries in Asia that Japan intended to discuss in building AMF rather India along with SAARC and GCC and western Asian countries have economic role to play in Asia as well as in the world. Therefore, if Asia requires a separate monetary institute to solve the exchange rate volatility, the international payment mechanism, the shortage of international liquidity and the developmental funds in solving crises then ASEAN, SAARC, GCC, Japan, Korea and China must be integrated themselves avoiding dominating tendencies for setting up Asian Monetary Fund in true sense similar with Euro Area's European Central Bank and it will be a feasible step to speed up Asian economic integration process.

\section{Literature Review}

Before the birth of AMF, the plan was dismissed by USA, the treasury of IMF and China, so that the concrete economic literature that are available up till now are not showing its absolute stage and framework. However, some important studies related with my current research article have been incorporated here. Kawai (2015) stated that originally, Japan proposed to set up Asian Monetary Fund at the Conference of Chiang Mai Initiative in Thailand ,2007, soon after the Asian Financial crisis. The fund will supply emergency fund for crisis prevention, management and resolution as a supplement of IMF with the mobilisation of 100 billion US Dollar at the beginning which was to pull foreign exchange reserves of East Asian countries to deter currency speculation and solve the contagion effects too. This plan was supported by the major nations of ASEAN and Korea but it was opposed by China, USA and the IMF in which IMF felt that it would create moral hazard and hit the global crisis management of IMF. Author felt that AMF could serve as a complementary organization and a building block of the global financial architecture provided by the IMF exchanging information on a routine basis, conducting joint analyses-as for the Financial Sector Assessment Program and Article IV consultation-and intervening in crisis countries together if needed. On the other hand, author emphasised that the formation of Asian Currency Unit can be instrumental effect on removal of financial crisis and liquidity crisis for Regional Economic Surveillance which was not developed yet in a systematic framework for monitoring exchange rate movements and for assessing countries' exchange rate policies. Even, the author thought that it would be effective to transform the Chiang Mai Initiative Multilateralization into an Asian 
Monetary Fund to strengthen the effectiveness of regional economic surveillance to formulate lending conditionality independent of IMF programs.

In analysing its earlier stages, Amyx (2002) clarified that the idea behind the regional institution like AMF in the heads of Japan was long before the inception of ADB in 1966 because Japan was emerging as a second dominating country in global economy and the chief dominating country in Asia. Therefore, after the Asian financial crisis, Japan proposed to set up Asian Monetary Fund to deal with liquidity supply during the crisis management and for monetary cooperation among Asian states. Thus, Japan initially pursued Sakakibara's conceptualisation of an AMF without the United States. At G7 meeting in Hong Kong in September 1997, EU and USA had strongly opposed this proposal. Although, US-Japan and ASEAN-Japan relations were economically reliable except with China who did not agree with this proposal and finally it was stopped to proceed although in the Manila conference the idea was revisited in Asian countries. In Miyazawa initiative, some steps for AMF were also discussed. In January 1999, the ASEAN+3 first met to discuss the establishment of a permanent regional fund for Revitalisation of the Asian Economy from financial crisis. After finalisation of ASEAN+3 currency swap policies multilaterally in CMI and after, the interest of Japan allies with US was becoming deemed gradually.

Philippi (2004) had titled the attempt of forming an AMF as semi-autonomous East Asian version of the IMF where Japan's contribution was planned as 50 billion US\$ in the 100 billion US\$ which would be used to future crisis in the Asian region. The Washington consensus rejected it. On the other hand, AMF can be reformed in ASEAN+3 along with pacific nation in which the aim was also cancelled by Bergsten symbolising as "Greater East Asia Common Yen Bloc". Somebody called it "East Asian crony capitalism".

On the obstacles of building AMF, Eichengreen (2003) clearly focussed about the formation of Asian Monetary Fund which was unsuccessful for launching because of Japanese supremacy over Asian finance and trade that was quite opposed by China who is now early cooperating the ASEAN+3 progress of East Asian monetary integration. However there are many barriers for Asian Monetary Surveillance for forming an separate institutions which are mainly related to [i] homogeneity of Asian countries,[ii] Asia is less economically self-contained than other regions,[iii] low degree of political integration,[iv] Asian governments are suspicious of strong supranational institutions,[v]Asian countries fear on floating rate, [vi]avoid common basket peg,[vii]low credibility and flexibility about capital market liberalisation,[viii]less cooperative on financial support and so on.

There are many positive or favourable reasons for forming of AMF in which Kenen and Meade (2006) illustrated that in establishing Asian Monetary Unit through basket of currencies for monetary integration in East Asia through the process of CMI can be a meaningful attempt to set up AMF on the condition that there should not be any domination struggle on the part of China as well as Japan and there should not be any competition between AMF and IMF.

Rajan (2000) had noted clearly the six good reasons in favour of AMF which include [i] regional financial crisis and contagion could be easily solved by AMF rather than heavy burden on IMF,[ii] the emergence of regional institution which is originally demanded by East Asia has the potentiality in resource, efficiency and facilities,[iii] an AMF can complement other East Asian efforts to facilitate regional economic development and interaction,[iv]East Asia would be enriched by getting regional facility in international financial market,[v] in setting up AMF, there is no hegemony of USA or EU, ,[vi] AMF is competent with dealing of financial crisis and contagion effects that might spread to other regions.

Narine (2003) exposed many favourable effect of Asian Monetary Fund that the Asian countries may enjoy such as[i]it can strengthened ASEAN,[ii]it can independently solve the problem of Asian liquidity crisis,[iii]it can enhance Asian monetary integration and accelerated the process of ASEAN single currency,[iv] it can envelop the early warning mechanism and watchdog over Asian economies,[v] good relationship is necessary with IMF,[vi] it can assist the Asian developmental model,[vii] it can protect Asian countries from being forced into structural adjustments,[viii] it can preserve Asian economies against the forces of change, like the catastrophic effects of a future investor panic or the other kinds of economic instability that might be produced by the 
volatile world financial system,[ix]it can extend its areas to Asia Pacific regions also,[x] It has no noncooperative motive with the west,[xi]the leadership can be solved in ASEAN+3 agreements.

Lipscy (2003) rightly mentioned by studying the historical perspective by Japanese initiative to launce AMF through a series of bilateral discussions that the attempt is Asian Sense of solidarity and to avoid US dominance in IMF, while it intends to a "small" package focusing on stabilization of the exchange rate through cooperative interventions in the currency market. On the other hand, USA and IMF rejected it by emphasizing moral hazard and showed that easy liquidity would allow Asian economies to postpone important domestic reforms.

On the contrary, Takashi (2003) argued that Japan's intention was to attempt a collective mechanism to protect the region's economies from violent and seemingly capricious changes of capital flows in the international financial market and to extend hard currency credit to economies in the region facing external liquidity difficulties in which IMF's liquidity provision in Asian financial crisis is low and unable to cope with capital account crisis and even IMF's conditionality resulted aggravation of financial crisis. However, in Manila conference, this concept was compromised and the AMF initiative was not completely lost.

Lee (2006) mentioned that Japan's aims was to lead crisis management solution and to build influence in Asia playing a regional leadership role through the process of Asian model of economic development against the U.S.-led IMF's imposition of neoliberal economic order. ASEAN+3 in CMI with currency swap arrangement is still existing hope of establishing AMF where China initially opposed this plan.

Anas and Friawan (2008) stated that if ASEAN+3 financial cooperation speed up towards setting up Asian Monetary Fund then IMF will be redundant for Asian regional development. This target also requires sound political integration process in Asia.

Above all, it should be think that the AMF requires an efficient leadership where Pitakdumrongkit (2019) thought that there should be clear leadership formation between China and Japan and even Korea's role along with ASEAN's ability to maintain financial cooperation principles were unknown at present in context of the governance, operational and technical areas and therefore, without such clear leadership, the prospects of enhancing the governance of the East Asian financial architecture seem modest at best.

Stromseth (2019) mentioned that the speedy uprising of Chinese economy and trade-war with USA has produced constant pressure on ASEAN to widen distance from China that may hinder the CMI progress of ASEAN+3 and US dollar payment mechanism where US-Japan economic and political relation will also hamper. This geo-political relation in Asian integration could not find any alternative way out from AngloAmerican hegemony.

Hyun and Paradise (2020) claimed that merging Chiang Mai Initiative Multilateralism with ASEAN+3 Macroeconomic Research Office for achieving financial and monetary stability in Asia may be a unique surveillance process to create an Asian Monetary Fund.

Zhang(2020) commented that the debate over AMF can be clarified in three folds,[i] the creation of the AMF would be beneficial to both Asia and the world because it support liquidity and strengthen the financial cooperation in East Asian region and in global level,[ii] on the US side it is complementary as a resistance since foreign exchange reserves, bilateral currency swap agreements, regional liquidity support arrangements, and the global arrangement (IMF) are the indicators of global safety nets,[iii]AMF wishes to delink from IMF conditionality because,[a]Asian countries have been suffering from debt crisis and less capable of full capital account convertibility,[b]although full capital account convertibility is not necessary to conditionality in IMF during last 20 years for confronting the crisis,[c] European Stability Mechanism clearly handled the debt crisis linking with conditionality. Above all, AMF consists of several challenges, like [i] over past 20 years Asia had not faced severe financial crisis, [ii]with a low degree of monetary integration in ASEAN+3, the setting up of AMF is over ambitious,[iii]Bergstein(1998) suggested that if USA joins then problem of AMF establishment would be solved,[iv]mutual trust and political cooperation are essential,[v]ASEAN+3 has scope to reform in CMIM where the great changes had occurred in China and Japan on their GDP share in the World as well as in Asia. 


\section{Methodology and sources of data}

In calculating the valuation of Currency Unit of Asia, the author used the technique of Polak $(1974 ; 1979)$ which the IMF had followed in creating SDR valuation of the basket. Even, the author has taken help from the book of Grubel (1977) to find the value of Currency Unit of Asia. The concept of Currency Unit of Asia which is a part of world currency unit was originated from the thought of Keynes (1942) Bancor as international money. The currency unit of Asia is a basket of currencies consisting of SAARC Currency Unit, ASEAN Currency Unit, GCC Currency Unit, Yuan, Yen and Won respectively. This new currency unit is the common currency of Asia of the new Asian Monetary Fund which is rather different idea from the original plan of Japan. The data on export and import shares, GDP share of SAARC, ASEAN, GCC, China, Japan and Korea in Asia in 2020 have been collected from UNCTAD and foreign exchange reserves of above blocs and countries have been taken from International Financial Statistics-2020(IMF). The value of gold and value of SDR were obtained from the IMF. Several important research papers from journals, occasional papers, working papers, policy briefs, and reports were incorporated in this paper for analysis.

\section{Purpose of the paper}

The author endeavours to explore a plan of forming a separate monetary fund for Asia for accelerating the progress of financial and trade integration in Asia with a view to issuing a separate common currency for Asia so that it can function as an Asian sovereignty and identity with the keen cooperation with IMF but without conditionality and structural adjustment facilities and will work for development and liquidity crisis of Asia. The new Asian bloc is the composite blocs of SAARC, ASEAN, GCC along with three big giants China, Japan and Korea. This bloc will set up Asian Monetary Fund which was originated from Japan. The author formulated its structure, functions, prospects and feasibility with certain limitations.

\section{An Extended Form of An Asian Monetary Fund}

If ASEAN, SAARC, GCC, China, Japan and Korea be the blocs/countries of a New Asian Bloc during the Asian economic process then the new Asian Monetary Fund can be set up consisting of these blocs and dominant countries in Asia where the chief economic indicators imply that China is the chief dominant country whose export and import shares and GDP share in this new Asian bloc is the highest followed by ASEAN, Japan, SAARC and GCC respectively. In case of foreign exchange reserves, China constitutes highest reserves followed by Japan and ASEAN. In Table-1, all the indicators are given below.

Table 1. Major indicators

\begin{tabular}{|c|c|c|c|c|}
\hline Country & $\begin{array}{c}\text { Export share in Asia } \\
(\% \text { in 2020) }\end{array}$ & $\begin{array}{c}\text { Import share in Asia } \\
(\% \text { in 2020) }\end{array}$ & $\begin{array}{c}\text { GDP share in Asia } \\
(\% \text { in 2020) }\end{array}$ & $\begin{array}{c}\text { Foreign exchange } \\
\text { reserves (in million } \\
\text { US\$ in 2020) }\end{array}$ \\
\hline ASEAN & 22.67 & 23.07 & 10.42 & $1200926(15.75 \%)$ \\
\hline SAARC & 5.64 & 4.22 & 11.78 & $729051(9.56 \%)$ \\
\hline GCC & 10.38 & 8.20 & 4.94 & $672187(8.82 \%)$ \\
\hline China & 42.42 & 38.82 & 49.86 & $3238782(42.49 \%)$ \\
\hline Japan & 10.50 & 11.55 & 17.33 & $1344283(17.63 \%)$ \\
\hline Korea & 8.39 & 9.15 & 5.67 & $437112(5.73 \%)$ \\
\hline
\end{tabular}

Source: UNCTAD and IFS(IMF)-2020.

The feasibility of forming a new Asian Monetary Fund in this new Asian bloc is bright since the progress of policies on monetary and trade integration towards the targets of formation of single currency have been continuing in SAARC, ASEAN and GCC so that GCC+SAARC+ ASEAN+3 could be a good Asian surveillance in Asian monetary system without creating moral hazards in IMF. The new Asian Monetary Fund is marginally different from the original plan of Japan and different from CMI. The following are the chief functions of this fund.

[i] It will act as a central bank of all central banks of the regional countries as well as bloc central banks.[ii] It will select common currency in Asia and act as a clearing window of Asian currencies and Currency Unit of Asia,[iii]The clearing window of AMF will maintain/calculate daily exchange rate of CUA with other regional common currencies 
in the basket,[iv]it will maintain exchange rate regulation, management and will formulate exchange rate policy,[v] It will maintain floating exchange rate with CUA with the basket of currencies,[vi] it will peg the rates of currencies in SAARC ,ASEAN and GCC with CUA,[vii]it is separate financial institution in Asia for Asia's sovereignty, surveillance and monetary stability,[ix] it will supply liquidity and developmental funds in Asia in times of crisis,[x] it will maintain complementarity with IMF,ECB,ADB, AfDB etc,[xi] it will monitor capital market in Asia,[xii]it will accelerate the process of monetary and financial integration in Asia,[xiii]it will formulate necessary policies to fulfil OCA criterion, [xiv]it will discourage key currency hegemony,[xv]it will deteriorate the heterogeneity indicators of least developed countries in SAARC,ASEAN and GCC,[xvi]it will continue dialogues with IMF to cooperate its functioning and to include CUA in SDR basket for smooth functioning of International monetary system,[xvii] it will negotiate in every aspects of multilateral and regional trade agreements with WTO and UNCTAD.

In Table 2, the weights of the regional bloc currencies and individual country's currency have been computed on the basis of average of export and import shares and GDP share in Asia in which Chinese weight is the highest followed by ASEAN, Japan, SAARC, Korea and GCC respectively, so that currency per CUA can be converted and even all currencies can be converted into SDR and gold also where it is assumed that 1CUA=1 Yuan at the beginning and unit of currency in 1 CUA can be easily computed.

Table 2. Currencies of blocs and countries (As on 13.10.21)

\begin{tabular}{|c|c|c|c|c|c|c|c|}
\hline Country/bloc & $\begin{array}{c}\text { Name of } \\
\text { currency (other } \\
\text { than common } \\
\text { currency) }\end{array}$ & $\begin{array}{c}\text { Weight of } \\
\text { currency } \\
(\%)\end{array}$ & 1gm of gold= & 1SDR= & 1Yuan= & $\begin{array}{c}\text { Unit of } \\
\text { currency in } \\
1 \text { CUA }\end{array}$ & $\begin{array}{c}\text { Yuan } \\
\text { equivalent } \\
\text { of CUA }\end{array}$ \\
\hline ASEAN & Ringgit & $16.65 \%$ & 235.52 & 0.17011 & 0.706 & 0.1175 & 0.1665 \\
\hline SAARC & Rupee & $9.60 \%$ & 4405 & 0.00942 & 13.221 & 1.2692 & 0.0960 \\
\hline GCC & Riyal & $7.11 \%$ & 211.94 & 0.19498 & 0.636 & 0.0452 & 0.0711 \\
\hline China & Yuan & $45.24 \%$ & 333.18 & 9.09610 & 1.0 & 0.4524 & 0.4524 \\
\hline Japan & Yen & $14.18 \%$ & 6408.89 & 159.893 & 19.235 & 2.7275 & 0.1418 \\
\hline Korea & Won & $7.22 \%$ & 67712.90 & 0.000594 & 203.23 & 14.6732 & 0.0722 \\
\hline & & 100.00 & & & & & 1.00 \\
\hline
\end{tabular}

Source: IMF (1 gm gold=1.125275SDR,1SDR=0.888671 gm of gold=1USDollar in 1974). (Since, the common currency of SAARC, ASEAN and GCC are not realised till today, then the Indian Rupee in SAARC, Malaysian Ringgit in ASEAN and Saudi Arabian Riyal in GCC are considered for explanation in forming CUA). [The author has calculated the values of column 3,6,7, and 8]. In Figure 1, the currency unit of Asia is shown.

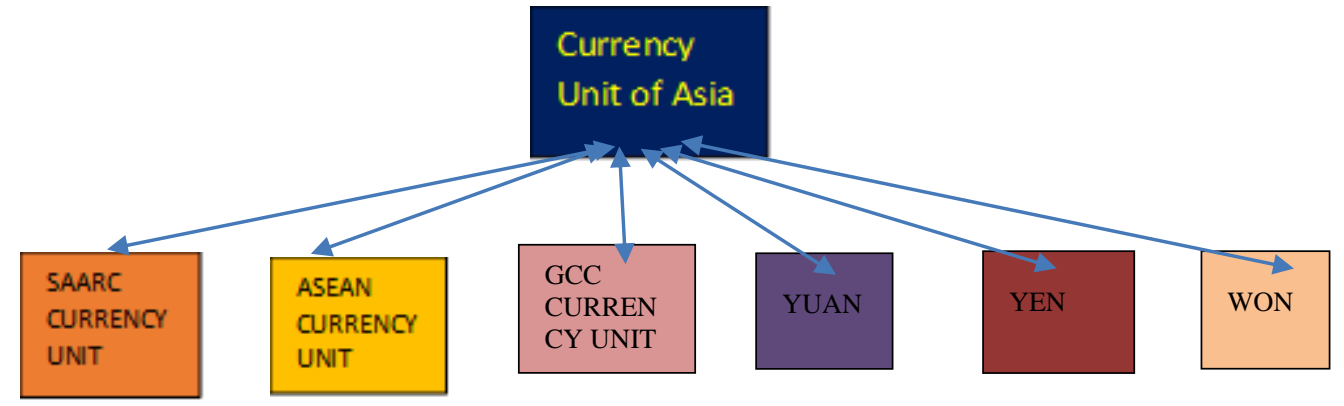

Figure 1. Currency Unit of Asia

Source: Plotted by author.

The axioms of properties of currency unit of Asia can be given in the following manner.

[1] The unit of account of CUA is either gold or silver, [2] it can be exchanged with SDR, Euro, or US Dollar, [3] IMF can include CUA into SDR basket, [4] CUA is exchanged with individual country's currency of SAARC,ASEAN or GCC and with China, Japan and Korea although it can be linked with SAARC currency unit, ASEAN currency unit and GCC currency unit respectively, [5]it is better to fix CUA exchange rate with SDR ,Euro and US Dollar with a target zone of fluctuations of $\pm 2.5 \%$, [6]but CUA will float along with other 
regional currencies of SAARC, ASEAN, and GCC and with Yen, Yuan and Won respectively, [7] initially, CUA can be set as 1Yuan=1CUA, [8] CUA can be linked to the international money(if there is any in the concept of 'Bancor' assumed by Keynes(1942)) as well as with African currency units, Latin American currency units and other currency units, [9] The OCA criteria of CUA must be monitored by AMF, [10] The weight of currencies/ currency units have been calculated by the average values of shares of export and import and share of GDP in Asia as on 13/10/2021, [11] The initial capital mobilisation of AMF will be 250 billion US\$ in which ,China, Japan, ASEAN, SAARC will contribute 50 billion each and the rest will be contributed by Korea and GCC, [12] CUA will be convertible into gold and Yuan in both capital and current account, [13] CUA can be exchanged with Euro, SDR and US\$ with fixed exchanged rate mechanism which will be determined by AMF.

\section{Barriers of new Asian Monetary Fund}

Since the first attempt of setting up AMF with the idea of Japan and it was ruined by USA and IMF autocracy then there are numerous barriers to form the AMF in a new world monetary order under a new Asian bloc which is yet to be admitted by WTO, and other international institutions. Even there are many economic barriers in forming economic integration. Bhowmik (2007) examined that in SAARC, the convergence of inflation and inflation differentials were not significant and favourable during 1968-2000, interest and interest rate differentials were not convergent during 1981-2000, there was no fiscal convergence during 1970-2000 and there was no debt/GDP convergence during 1982-2000. It was also verified that SAARC has been facing with asymmetric shocks of output, money supply, exchange rate and current account balance respectively. Later, Bhowmik (2014) found out that SAARC during 1978-2006 satisfied the Beta convergence of OCA criterion in inflation, interest rate, fiscal deficit and debt/GDP ratio. In response to a plan for common currency in SAARC of Bhowmik (1998), Maskay $(2005 ; 2003 ; 2001)$ raised the issues of problems behind the common currency that due to asymmetric shocks, incomplete of monetary and financial integration process halted the progress of single currency in SAARC. The other important obstacles in SAARC can be mentioned as,[i] Pakistan's noncooperation and anti-Indian war motivation and Afghanistan invasion by Taliban have been halted the progress of SAARC in all dimensions, [ii] underdevelopment and incomplete capital market reform hampers the progress of single currency,[iii] heterogeneous factors in socio-political events disturbed the SAARC progress,[iv] financial sector reform and convertibility process are in initial stages,[v] SAFTA should be renovated.

Bhowmik (2014) examined that during 1968-2006, ASEAN satisfied the Beta convergence OCA criteria in inflation rate and fiscal deficit but did not satisfy the interest rate and debt/GDP convergence and even ASEAN+3 did not show significant Beta convergences in those criteria. In addition to that in SAARC+ASEAN bloc, only inflation rate convergence was significant during 1968-2006 and suffered from asymmetric shocks in output, money supply, exchange rate and current account balance respectively. Later, Bhowmik (2021) studied that ASEAN during 1990-2017, have significant Beta and Sigma convergence in fiscal deficit and debt/GDP but have insignificant convergences in interest rate, exchange rate and inflation rate. Even, equity, share, stock and bond markets have to be more internationalised and full convertibility require speedy reforms in financial sectors. The most important barriers are classified as,[i] political hegemony collapsed the sovereignty of ASEAN, [ii] CMI is necessary but not sufficient condition for adoption of common currency for ASEAN,[iii] less developed countries like Lao PDR, Myanmar hamper the homogeneity in ASEAN [iv]capital market integration is not ripe for single currency,[v] domination of Dollar halted the progress of single currency because ASEAN+3 supported Dollar as the vehicle currency,[vi] Asia-Pacific region in the framework of ASEAN+6 is neither favourable nor essential for monetary and trade integration in ASEAN for single currency,[vii] new policy reforms are needed for speedier AFTA.

Ahmad (2021) studied that GCC is quite ripe for common currency and satisfied the OCA criteria during 20112017 in the style of Maastricht treaty and it has created greater Arab Free Trade Agreements and fixed OCA criteria and even admitted that Khaleeji will be the common currency of GCC where 1US $\$=1.984 \mathrm{KHJ}$ was agreed by the region. Bhowmik (2021) examined that GCC has positive impact on SAARC and ASEAN export and import shares and long run causalities during 1995-2019 so that Asian integration process can accelerate. But, Bentour (2018) mentioned that the region suffers from oil price volatility, inconsistencies in setting OCA 
criteria and 4+2 countries non-homogeneous characters which hampered the process of single currency. Specifically, the other barriers are, [i] currency peg with US Dollar in GCC, [ii] current account surplus in the region, [iii] financial and capital market are less internationalised, [iv] GCC is not fully benefitted by SDR, Euro, gold and oil prices, [v] it is a zone of war that has halted openness and internationalisation, [vi] the sociopolitical factor like caste and religion and US hegemony are the other important barriers.

Finally, the historical rivalry between China and Japan has destabilised the progress of New Asean Bloc (=SAARC+ASEAN+GCC+3) which can be brought up a sound and stable Asian Monetary Fund where the roles of China and Japan are assumed as pivotal in Asia in deciding to challenge the US hegemony in forming a separate Asian Monetary System with its common currency or currency unit in a basket peg where US dollar without any standard and unit of account should be discouraged. Both of the currencies of China and Japan are included in the SDR basket which have key roles in the international monetary system. Therefore, the international payment mechanism in the arena of international trade and finance also depends on both Yen and Yuan that can help to emerge an Asian Monetary System at least in the Asian context without intervention of USA. Without inclusion of SAARC and GCC in Asian region, the previous thought on Asian Monetary Fund regarding the chief barriers were fully justified in the sense that Hyun and Paradise (2019) explained that China observed closely that Japan during last 4 decades was trying to dominate ASEAN and has maintained leadership in Asian Development Bank and Asian Infrastructure Investment Bank (AIIB). In ASEAN+3, both China and Japan have shared their role of leadership. In this region there are high dependency of US Dollar as exchange rate mechanism. The CMI also helped to accelerated the multilateralism through currency swap system.EU has been progressing towards EMF through the advancement of European Stability Mechanism (ESM) having their $\mathrm{ECB}$, then why not Asia will advance towards the formation of AMF with the progress of CMIM. But the main obstacle is the Sino-Japan rivalry which is a historic one.

On the other hand, Narine (2003) conceptualised that most of the Asian countries may not prepared to face global US dominance over international finance and monetary cooperation in setting up regional Asian Monetary Fund because they suffer from leadership issue to run the institution rather ASEAN monetary integration and the AFTA with the setup of ASEAN+3 may solve the problem but the question of rivalry between China and Japan would create destabilisation where China making friend with USA and IMF withdrew the support of its emergence to oppose Japanese dominance over Asian finance and trade. In the long run, an effective AMF has the potential to further divide ASEAN and co-opt its economic aspirations. Although the author thought that AMF as a substitute of IMF for Asian finance to defend a model of "Asian developmental capitalism" as an alternative to Anglo-American capitalism can be effective for Asian development where AMF would build on Asia's savings surplus, foreign exchange reserves, and net-creditor status to finance the debt of the Crisis-affected Asian countries.

\section{The shortcomings of the plan}

The countries e.g., Tibet, Mongolia, North Korea, Yemen, Jordon, Israel, Iran, Palestine, Lebanon and Syria were not included in AMF because only regional bloc member countries were included here. It is admitted that the actual Asian integration is not fully reflected in Asian Monetary System. The fact is that those countries were involved in war and other political and economic disputes, unrest and function as dis-integrated manner. In due course, the countries can be included in the respective blocs through successive agreements and discussions with the initiatives of UNO, G7 and other international institutions.

Since, AMF of earlier framework was not realised then this thought may not be treated as feasible solution of Asian Economic Integration to many leaders of EU, NAFTA and IMF. Yet, this integration process may come true in the offing as a better possibility of Asian economic integration.

The most important shortcoming is that in the present day, currency basket system of monetary and financial system is not preferred by monetarists rather they are eager to go forward with dollar hegemony. But the world monetary stability fears that the US dollar is not backed by any unit of account after the collapse of Bretton Woods. 
The same plan can be realised through the ADB from a separate window under a general consensus where no veto from USA and IMF should not be given. This idea is a controversial concept which requires a series of discussions and agreements among members.

\section{Conclusion}

On the successful policy issues in CMI, Kawai (2019) emphasized on Asian Bond Market Initiative and Rana (2017) advised to keep close relation among AMRO, IMF and CMI. But the above plan of forming a new Asian Monetary Fund requires more policy prescriptions like building of Asian Stock Exchange Institute, Asian Security Council, Asian Parliament, Asian Clearing Union and Asian Central Bank for stronger political integration and financial integration in Asia. The paper has given a clear picture about a new Asian Monetary Fund in a new Asian bloc which is yet to be materialised however the feasibility constraints are minimum to realise it because all the existing blocs that were mentioned in the paper have been spent many years of economic integration process. Yet, in selecting the unit of account of the common currency in Asian bloc is controversial in theory and in practice to many monetarists in Asia and the world because some monetary economists do not prefer currency basket system. Whether it will emerge with the help of EU, USA and IMF or whether it will emerge as an Asian identity only that depends on the hegemony on US Dollar or hegemony of IMF which can give birth of a new Asian Monetary Fund in practice. Finally, the idea of the integration process of CMI plus pacific regions and the integration process of SAARC+ ASEAN+ GCC+3 for a concrete Asian bloc and the Asian Monetary Fund are rather different and the structural frameworks are not identical where the political feasibility and the economic feasibility will not be mutually exclusive.

\section{Acknowledgement}

In preparing this paper, I am indebted to all sources of references, the authority of the journal and other wellwishers. I declare that no organisation/NGO/institution have sanctioned the funds to publish this work. I am responsible for all errors and omissions.

\section{Conflict of Interest}

There is no conflict of interest in the process of the paper publication.

Funding: self-funded.

Author contribution: conceptualization, Debesh Bhowmik; data curation, Debesh Bhowmik; formal analysis, Debesh Bhowmik; funding acquisition, Debesh Bhowmik; investigation, Debesh Bhowmik; methodology, Debesh Bhowmik; project administration, Debesh Bhowmik; resources, Debesh Bhowmik; software, Debesh Bhowmik; supervision, Debesh Bhowmik; validation, Debesh Bhowmik; visualization, Debesh Bhowmik; writing - original draft, Debesh Bhowmik; writing - review \& editing, Debesh Bhowmik.

\section{References}

1. Ahmad, W. (2021). Common Currency Area in GCC region: An Application of Euro Model. American Journal of Industrial and Business Management,11,905-923. [CrossRef].

2. Amyx, J. (2002, September). Moving Beyond Bilateralism? Japan and the Asian Monetary Fund. Asia Pacific Economic Papers, No. 331, Australia-Japan Research Centre, Crawford School of Public Policy, The Australian National University. [GoogleScholar].

3. Anas, Titik., \& Friawan, Deni. (2008, February). Future role of the IMF: Asian Perspectives. FES Briefing Paper 1, Berlin. [GoogleScholar].

4. Asami, Tadahiro. (2001, August). After the Chiang Mai Initiative. IIMA NEWSLETTER, 5, 1-8. [Link].

5. Bentour, El Mostafa. (2018). Review of monetary union criteria and prospect of the GCC monetary union experience. GREG (halsha-03007632). [Link].

6. Bergsten, Fred. (1998, December). Reviving the "Asian Monetary Fund". Policy Brief, 98-8. Washington, DC: Peterson Institute for International Economics. [Link]. 
7. Bhowmik, Debesh. (2007). Steps towards monetary integration of SAARC. In Pran Krishna Pal (Ed.), Economic Growth and Development: Emerging Issues. New Delhi: Deep and Deep Publication Pvt. Ltd. pp.182-220. [GoogleScholar].

8. Bhowmik, Debesh. (2014). Asian Economic Integration: Feasibility of an India-led Economic bloc. New Delhi: Regal Publications. [Link].

9. Bhowmik, Debesh. (2021). Gulf Cooperation Council (GCC) and Regional Integration in Asia. Financial Markets, Institutions and Risks,5(1),61-79. [CrossRef].

10. Bhowmik, Debesh. (2021). Empirical Study on the Prospects of ASEAN's Trade and A Single Currency. Asian Journal of Social Sciences Review,3(1). [GoogleScholar].

11. Bhowmik, Debesh. (1997-1998, July-September). Monetary Co-operation of SAARC: A plan for a Single Currency. The Indian Economic Journal.45(1), 138-145. [GoogleScholar].

12. Eichengreen, Barry. (2003). What to Do with the Chiang Mai Initiative. Asian Economic Papers, 2(1), 1-49. [CrossRef].

13. Hyun, S., \& Paradise, J.F. (2019). Why Is There No Asian Monetary Fund? ADBI Working Paper 1061. Tokyo: Asian Development Bank Institute. [Link].

14. Hyun, S., \& Paradise, J.F. (2020, June). Toward an Asian Monetary Fund: Ideas for Transition. Asian Economic Papers, 19 (2), 65-77. [GoogleScholar].

15. Grubel, Herbert G. (1977). The International Monetary System: Efficiency and Practical Alternatives. London: Penguin Books Ltd. Third Edition. [Link].

16. Kawai, M. (2015). From the Chiang Mai Initiative to an Asian Monetary Fund. ADBI Working Paper 527. Tokyo: Asian Development Bank Institute. [Link].

17. Kawai, Masahiro. (2019). Asian Bond Market Development. ERINA Discussion Paper No. 1901e. Economic Research Institute for North East Asia: Niigata, Japan. [GoogleScholar].

18. Kenen, P.B., \& Meade, E.E. (2006). Monetary Integration in East Asia. Proceedings, Federal Reserve Bank of San Francisco, issue June. [Link].

19. Keynes, J.M. (1942). Proposals for an International Currency (or Clearing Union: Fourth draft of the Keynes plan. Reprinted in Horsefield, J.K. (1969), The International Monetary Fund 1945-1965, Volume 3, Documents (Washington D C. International Monetary Fund), pp. 3-36. [Link].

20. Lee, Yong Wook. (2006, June). Japan and the Asian Monetary Fund: An Identity-Intention Approach. International Studies Quarterly, 50(2), 339-366. [GoogleScholar].

21. Lee, Yoon Jin. (2010). Financial Community Building in East Asia, The Chiang Mai Initiative: Its Causes and Evaluation. EPIK, Economics of Community Building. [Link].

22. Lipscy, Phillip Y. (2003). Japan's Asian Monetary Fund Proposal. Stanford Journal of East Asian Affairs, 3(1), 93-104. [Link].

23. Maskay, Nephil Matangi. (2005). Common Currency Area: Prospects for South Asia. In Nepal Rastriya Bank (Ed.), Economic Integration in South Asia, Nepal, pp. 51-56. [Link].

24. Maskay, Nephil Matangi. (2003). Patterns of Shocks and Regional Monetary Cooperation in South Asia. IMF Working Paper-WP/03/240. [Link].

25. Maskay, Nephil Matangi. (2001, September). South Asian Monetary Integration in Light of the Optimum Currency Area Criterion of Patterns of Shocks. South Asia Economic Journal, 2(2), 203-219. [Crossref].

26. Narine, Shaun. (2003). ASEAN and the Idea of an "Asian Monetary Fund": Institutional Uncertainty in the Asia Pacific. Asian Perspective, 27(2), 65-103. [Link].

27. Polak, J. J. (1974). Valuation and rate of interest of the SDR. Pamphet series No.18, Washington: IMF. [GoogleScholar].

28. Polak, J. J.(1979, December).The SDR as Basket of Currencies. IMF Staff Paper. Article no-A001,627653. [GoogleScholar].

29. Philippi, Clemens. (2004). Between "Washington Consensus" and "Asian Way": Japanese Newspaper Authors Discussing the East Asian Financial and Economic Crisis of 1997/1998. Japanstudien, 15(1), 281-314. [CrossRef]. 
30. Pitakdumrongkit, Kaewkamol. (2019). The Politics of East Asian Financial Agreement: The Case of the CMIM. In Tomoo, Kikuchi and Masaya, Sakuragawa (Eds.). Financial Cooperation in East Asia. Singapore: S. Rajaratnam School of International Studies, pp. 65-71. [Link].

31. Rajan, Ramkishen S. (2000). Examining the Case for an Asian Monetary Fund. ISEAS Working Papers, No. 3. Singapore: Institute of Southeast Asian Studies. [Link].

32. Rahman, M. Sigit Andhi. (2016). Multilateralism in East Asia: Analysis of Chiang Mai Initiative (CMI) within ASEAN+3 Framework. Jurnal Kajian Wilayah, 1(1), 101-118. [Link].

33. Rana, P. B. (2017). ASEAN+3 Regional Financial Safety Net and IMF: Time for Structured Cooperation. (RSIS Commentaries, No. 128). RSIS Commentaries. Singapore: Nanyang Technological University. [Link].

34. Stromseth, Jonathan. (2019, October). Don't make US choose Southeast Asia in the throes of US-China rivalry. Foreign Policy at Brookings. [Link].

35. Takashi, Kiuchi. (2003). The Future of ASEAN-Japan Financial Relations. In Japan Center for International Exchange (Ed.), ASEAN-Japan Cooperation: A Foundation for East Asian Community. Tokyo: Japan Center for International Exchange, pp. 108-124. [Link].

36. Zhang, Liqing. (2020, June 1). Comments on Toward an Asian Monetary Fund: Ideas for Transition. Asian Economic Papers, 19(2), 80-83. [CrossRef]. 